\title{
PERSEPSI DAN SIKAP WISATAWAN MILENIAL TERHADAP PARIWISATA DI ERA COVID 19
}

\author{
I Gusti Agung Febrianto \\ Program Studi Bisnis Hospitaliti , Politeknik Pariwisata Bali \\ Jl. Dharmawangsa, Kampial, Nusa Dua, Bali \\ igustiagung.febrianto@gmail.com
}

\begin{tabular}{l|l|l} 
Received: June, 2021 & Accepted: June, 2021 & Published: July, 2021
\end{tabular}

\begin{abstract}
The tourism sector has been predicted as the second largest source of foreign exchange contribution in Indonesia, but the Covid-19 pandemic has made this sector sluggish. The government is making various efforts so that the tourism sector can return to normal. The millennial generation relatively bolder when traveling when compared to the previous generation. With the opening of tourism era of covid 19, the millennial generation will immediately carry out travel activities. The purpose of this study is to determine the perceptions and attitudes of millennial tourists towards tourism era of covid 19. The perception of millennial generation tourists focuses on risks when traveling. Attitude is an evacuation of belief in positive feelings or negative feelings from someone if they have to perform a behavior that will determine. The number of respondents in this study were 100 tourists. The method used is descriptive quantitative. The result of this study is that millennial tourists' perceptions of tourism in the new normal era prioritize the quality of health protocols both in hotels, restaurants, transportation, and in tourist attractions. Likewise, the attitude of millennial tourists towards tourism in the new normal era is more concerned about safety, health and cleanliness when traveling.
\end{abstract}

Keywords: covid 19, tourist perception, tourist attitudes, millennial tourists.

\begin{abstract}
Abstrak
Sektor pariwisata selama ini digadang-gadang sebagai sumber kontribusi devisa terbesar kedua di Indonesia, namun pandemic Covid 19 membuat sector ini menjadi lesu. Pemerintah melakukan berbagai upaya agar sector pariwisata bisa kembali normal. Generasi milenial relative lebih berani ketika melakukan perjalanan wisata jika dibandingkan dengan generasi sebelumnya. Dibukanya pariwisata di era covid 19, generasi milenial akan segera langsung melaksanakan kegiatan perjalanan wisata. Tujuan dari penelitian ini untuk mengetahui persepsi dan sikap wisatawan milenial terhadap pariwisata di era covid 19. Persepsi wisatawan generasi milenial berfokus terhadap resiko saat melakukan perjalanan wisata. Sikap adalah sebuah evakuasi kepercayaan atas perasaan positif atau perasaan negatif dari sesorang jika harus melakukan perilaku yang akan menentukan. Jumlah responden pada penelitian ini adalah 100 wisatawan. Metode yang digunakan adalah deskriptif kunatitatif. Hasil penelitian ini adalah persepsi wisatawan milenial terhadap Pariwisata di era new normal lebih mengutamakan kualitas protokol kesehatan baik di
\end{abstract}


hotel, restaurant, transportasi, maupun di objek wisata. Begitu juga sikap wisatawan milenial terhadap Pariwisata di era new normal lebih memperdulikan tentang kesalamatan kesehatan dan kebersihan sata melakukan perjalananan wisata.

Kata Kunci: covid 19, persepsi wisatawan, sikap wisatawan, wisatawan milenial.

\section{PENDAHULUAN}

Pariwisata merupakan sumber devisa kedua terbesar di Indonesia. Namun pandemic Covid-19 membuat sektor ini menjadi lesu (Liputan 6; 2020). Bali merupakan ikon pariwisata Indonesia tidak luput juga terdampak oleh covid 19. Daerah tujuan wisata yang dimiliki oleh Bali seluruhnya ditutup dan tidak boleh ada wisatawan yang berkunjung. Hotel-hotel berbintang yang berada di Bali juga dengan terpaksa untuk menutup sementara mengingat tidak adanya wisatawan dan himbaun dari pemerintah untuk membatasi penerimaaan wisatawan yang ingin menginap.

Pemerintah Republik Indonesia melakukan berbagai upaya agar sector ini bisa kembali normal. Mulai dari pembatasan orang berpergian, menggunakan masker saat keluar dan selalu mencuci tangan. Matinya sector ekonomi dari pariwisata membuat pemerintah menerapkan hal-hal tersebut disetiap daerah tujuan wisata, akomodasi, dan restoran. Ketua Asosiasi Perusahaan Perjalanan Indonesia (ASITA) menerapkan kebijakan untuk mendukung pariwisata di era covid 19. Adapun kebijakan yang harus diterapkan antara lain protocol kesehatan, kebersihan, keselamatan, dan juga kemanan baik dari sisi pekerja maupun wisatawan(economy.okezone.com;2020) - Penerapan protocol kesehatan sangat penting dilakukan diberbagai sector agar rantai covid 19 bisa terputus.

Hasil penelitian yang dilakukan oleh UNWTO tahun 2015 menjelaskan bahwa generasi melenial pada tahun 2020 terdapat 370 juta perjalanan wisata. Hal ini membuktikan bahwa saat ini perjalanan wisata akan didominasi oleh wisatawan milineal. Menurut Garikapati et al (2016: 558) menjelaskan seseorang yang lahir dari tahun 1979-2000 disebut generasi milenial. Dapat dikatakan bahwa generasi milenial berkisar diatara umur 41-20 tahun. Di Bali sendiri, jumlah generasi milenial sebanyak 1.653 .500 jiwa. Tingginya generasi milenial dapat dikaitkan bahwa perjalanan kegiatan pariwisata saat ini didominasi oleh wisatawan generasi milenial merujuk dari penelitian yang dilakukan oleh UNWTO pada tahun 2015. Pada masa pariwisata di era covid 19 dapat diyakini wisatawan generasi milenial akan tetap melaksanakan kegiatannya. Menurut Perhusip dan Arida (2018; 299) menyatakan bahwa yang lebih berani melaksanakan kegiatan perjalanan wisata adalah generasi milenial ini. Dibukanya pariwisata di era covid 19, generasi milenial akan segera langsung melaksankan kegiatan perjalanan wisata.

Kegiatan perjalanan wisata yang dilaksanakan wisatawan generasi milenial akan memunculkan berbagai persepsi. Persepsi wisatawan generasi milenial berfokus terhadap resiko saat melakukan perjalanan wisata. Tertularnya virus covid 19 menjadi resiko terbesar. Selain persepsi, sikap wisatawan terhadap dibukanya pariwisata di era covid 19 ini perlu diperhatikan. Sikap peduli terhadap kebersihan merupakan hal utama yang harus dimiliki oleh wisatawan. Suprapti (2010;135) menjelaskan sikap merupakan hasil dari suatu proses psikologi, maka dari itu sikap tidak dapat diamati secara langsung, namun harus disimpulkan dari yang dikatakan atau dari apa yang dilakukannya. Sikap adalah sebuah evakuasi kepercayaan atas perasaan positif atau perasaan negatif dari sesorang jika harus melakukan perilaku yang akan menentukan. Sikap merupakan ciri yang dimiliki oleh seseorang dalam membentuk sebuah 
karakter, karakter tersebut merupakan prinsip yang dimiliki dan bersifat statis atau sulit berubah.

Berdasarkan uarian diatas, perubahan pesepsi dan sikap wisatawan akan berubah setalah adanya covid 19 . Oleh sebab itu peneliti tertarik untuk meneliti hal tersebut dengan judul Persepsi dan Sikap Wisatawan Terhadap Pariwisata di Era Covid 19.

Slameto (2010; 102) menjelaskan mengenai persepsi diartikan sebagai proses yang menyangkut masuknya pesan atau informasi kedalam otak manusia, melalui persepsi manusia terus menerus mengadakan hubungan dengan lingkungan. Menurut Suranto (2010) menjelaskan persepsi adalah proses individu untuk mengerti hubungan dengan dunia sekelilingnya. Persepsi adalah sudut pandang, gambaran dan tindakan terhadap sesuatu lingkungan disekeliling kita baik bersifat positif atau bersifat negative (Murianto, 2014). Menurut Sarwono (2009) persepsi adalah suatu pengalaman dalam membeda-bedakan, mengelompokkan, serta memfokuskan yang selanjutnya di interorientasi.

Menurut Sunaryo menjelaskan terdapat 2 hal yang akan mempengaruhi persepsi yaitu persepsi eksternal merupakan persepsi yang terjadi karena datangnya rangsangan dari luar individu. Self perception merupakan persepsi yang terjadi karena datangnya rangsangan dari dalam individu. Faktor-faktor berperan dalam persepsi dapat dikemukakan beberapa factor menurut Walgito $(2004 ; 70)$, antara lain objek yang dipersepsikan, alat-alat indera dan sususnan syaraf, serta perhatian terhadap sesuatu yang disadari atau yang diperhatikan.

Suprapti (2010;135) menjelaskan sikap menjelaskan hasil dari suatu proses psikologi dari sikap yang tidak diamati langsung. Sikap adalah sebuah evakuasi kepercayaan atas perasaan yang positif atau negatif seseorang apabila melakukan perilaku yang menentukan. Sikap merupakan ciri yang dimiliki oleh seseorang dalam membentuk sebuah karakter, karakter tersebut merupakan prinsip yang dimiliki dan bersifat statis atau sulit berubah. Merubah karakter diperlukan usaha yang cukup keras karena hal tersebut dijadikan sebagai dasar dalam kehidupan dan karakter sendiri marupakan bawaan sejak lahir. Sikap sebagai evaluasi negatif atau positif seseorang dari perilaku tertentu. Evaluasi merupakan aspek kognitif, sementara kesukaan merupakan aspek emosional. Suryani (2008) menjelaskan bahwa sikap memiliki tiga komponen pembentuk antara lain : kognitif, afektif, dan konatif.

Penjelasan di atas menunjukkan bahwa sikap mempunyai fungsi yang berbeda tergantung pada kondisi yang melingkupi individu. Dasar untuk memahami suatu perilaku individu adalah sikap. Melalui sikap yang ditunjukan akan diketahui bahwa individu tersebut memiliki pengetahuan yang cukup, banyak, atau tidak yang sama sekali mengenai objek sikap.

Menurut Sumarwan (2003:82) terdapat model sikap yang dikembangkan oleh Fishbein yaitu multi attribute attitude model. Model multi atribut ini menjelaskan bahwa sikap konsumen terhadap suatu model sikap (produk) sangat ditentukan oleh sikap konsumen terhasap atribut-atribut yang dievaluasi. Model tersebut disebut multi atribut disebabkan evaluasi konsumen terhadap objek berdasarkan dari evaluasi konsumen terhadap banyak atribut yang dimiliki oleh objek tersebut. Sikap konsumen terhadap pariwisata di era covid 19 antara lain kebutuhan kebersihan saat melakukan perjalanan wisata, peduli akan kebersihan dan keamanan, saatmenggunkan transportasi, peduli terhadap kebersihan dan keamanan saat di objek wisata, serta peduli akan kebersihan dan keamanan pada akomodasi. 


\section{METODE PENELITIAN}

Teknik pengambilan sampel yang digunakan dalam penelitian ini dilakukan dengan cara Accidental Sampling .Teknik ini menggunakan kuisioner yang disebarkan kepada wisatawan local yang berasal dari Bali yang tergolong milenial. Dalam menentukan jumlah wisatwan milenial dengan menggunakan rumus Slovin yaitu

$$
\mathrm{n}=\mathrm{N} / 1+\mathrm{N}(\mathrm{e}) 2
$$

Keterangan:

$\mathrm{N}=$ ukuran sampel/jumlah responden

$\mathrm{N}=$ Ukuran Populasi

$\mathrm{e}=$ Persentasi kelonggaran ketelitian kesalahan pengambilan sampel yang masih bisa ditolerir,e $=0.1$

Jumlah kunjungan wisatawan ke Taman Harmoni Bali pada tahun 2018 adalah 159.162 jadi jumlah responden adalah $\mathrm{n}=1.653 .500 / 1+1.653 .500(0.1) 2$ $=100$ wisatawan. Penyusunan penelitian ini menggunakan teknik-teknik pengumpulan data sebagai berikut:

1) Angket dengan menggunakan kuesioner terutama yang berkaitan dengan pemberian skor dan rating oleh pihak wisatawan generasi milenial. Dalam teknik ini disebarkan kuisioner kepada wisatan terkait persepsi dan sikap wisatawan milenial terhadap Pariwisata di era covid 19.

2) Dokumentasi, yaitu teknik pengumpulan data dengan mencari dokumen-dokumen resmi yang berhubungan dengan data penduduk
Indonesia yang tergolong generasi melenial.

Penelitian ini akan digunakan teknik analisa data yaitu Deskriptif Kuantitatif. Skala likert digunakan untuk mengukur sikap, pendapat, dan persepsi seseorang atau sekelompok orang tentang fenomena sosial (Sugiyono, 2002 : 86). Setiap jawaban kuisoner mempunyai bobot atau skor nilai dengan skala likert sebagai berikut:

Jawaban sangat setuju (SS) nilainya adalah 5

Jawaban setuju (S) nilainya adalah 4

Jawaban netral $(\mathrm{N})$ nilainya adalah 3

Jawaban tidak setuju (TS) nilainya adalah 2

Jawaban sangat tidak setuju (STS) nilainya adalah 1

\section{HASIL DAN PEMBAHASAN}

\subsection{Karakteristik Wisatawan}

Karakteristik wisatawan sebagai respoden pada penelitian ini dijelaskan berdasarkan jenis kelamin, usia, profesi, status, pendidikan terakhir, dan daerah asal. Penilaian responden terhadap indikator dalam penelitian ini akan dijelaskan lebih lanjut.

Responden pada penelitian ini adalah perempuan sebesar $41 \%$ dan responden laki-laki sebesar 59\%, hal ini menunjukkan bahwa tanggapan mengenai pariwisata di era covid 19 oleh wisatawan milenial berdasarkan jenis kelamin didominasi oleh wisatawan milenial laki-laki.

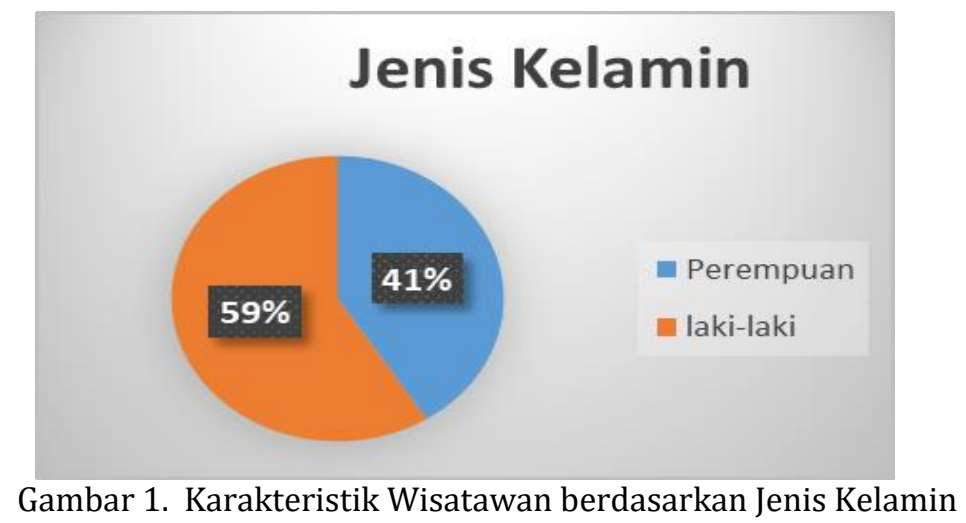

Karakteristik wisatawan berdasarkan usia dapat dilihat bahwa respoden usia
20-24 tahun sebanyak 59\%, usia 25-29 sebanyak $14 \%$, usia $30-34$ sebanyak 
Febrianto

10\%, usia 35-39 tahun sebesar 9\%, dan

wisatawan milenial usia 20-24 tahun usai 40-41 sebanyak 8\%. Kelompok mendominasi dalam penelitian ini.

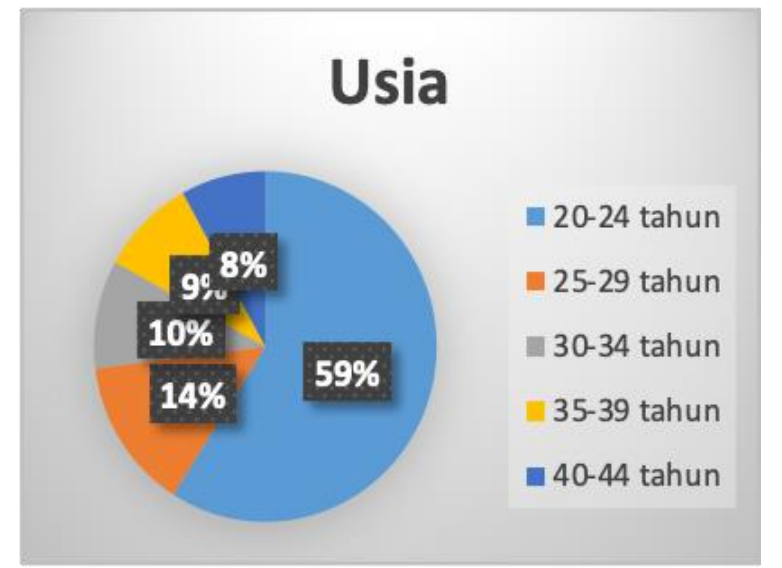

Gambar 2. Karakteristik Wisatawan berdasarkan Usia

Berdasarkan dengan profesi diperoleh data bahwa wisatawan berprofesi sebagai pelajar sebesar 39\%, karyawan sebesar 33\%, wirusaha sebesar 15\%, PNS sebesar 6\%, dan lainnya sebesar 7\%. Hal ini menunjukkan bahwa dominan wisatawan melenial yang memberikan tanggapan mengani pariwisata di era new normal dominan pelajar.

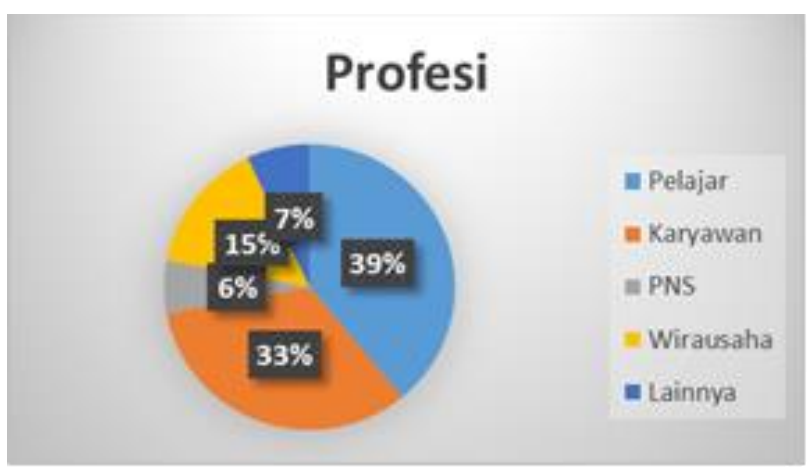

Gambar 3. Karakteristik Wisatawan berdasarkan Profesi

Responden pada penelitian ini adalah menikah sebesar 34\% dan responden belum menikah sebesar $66 \%$ persen, hal ini menunjukkan bahwa wisatawan milenial yang memberi tanggapan mengenai pariwisata di era new norma; berdasarkan status lebih dominan yang belum menikah.

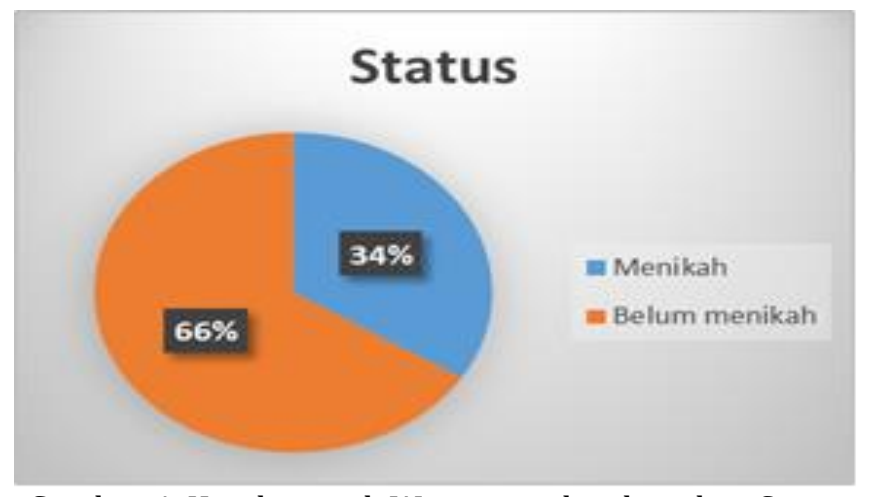

Gambar 4. Karakteristik Wisatawan berdasarkan Status 
Febrianto

Tingkat pendidikan wisatawan milenial yang memberi tanggapan mengenai pariwisata di era new normal dapat diketahui bahwa tingkat pendidikan Sarjana paling banyak dalam penelitian ini dengan persentase 65\%. Pendidikan terakhir SMP sebesar 1\%, diikuti oleh SMA 24\%, diploma 10\%.

\section{Pendidikan Terakhir}

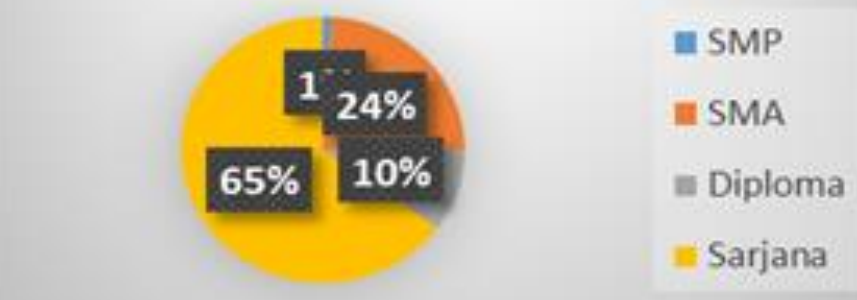

Gambar 5. Karakteristik Wisatawan berdasarkan Pendidikan Terakhir

Karakteristik wisatawan milenial berdasakan daerah asal pada penelitian ini dapat diketahui bahwa Gianyar paling banyak dalam penelitian ini dengan persentase $36 \%$, Denpasar sebesar 21\%, Badung 23\%, Tabanan 5\%, Jembrana 1\% ,Buleleng 2\%, Karangasem 7\%, Klungkung 4\%, dan Bangli 1\%.

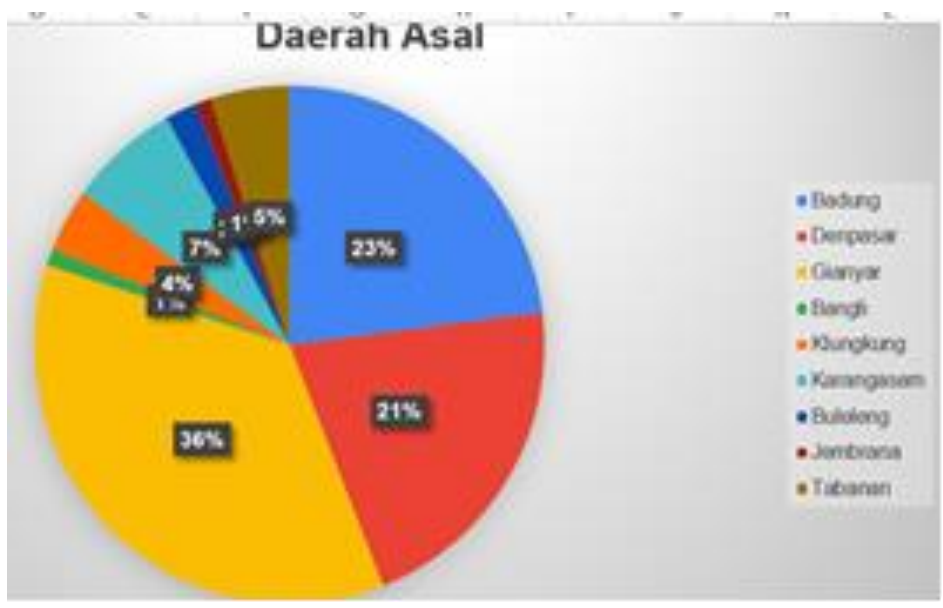

Gambar 6 Karakteristik Wisatawan berdasarkan Daerah Asal

\subsection{Persepsi Wisatawan Milenial Terhadap Pariwisata di Era New Normal}

Berdasarkan Table 1 menunjukkan bahwa penilaian persepsi wisatawan milenial terhadap pariwisata di era new normal berada pada nilai 3.45 yang berarti dalam kategori setuju. Secara keseluruhan persepsi wisatawan milenial terhadap pariwisata di era new normal mengarah ke persepsi positif yang man mengutamakan kualitas dari protocol kesehatan. Indikator persepsi wisatawan milenial tertinggi adalah pada kategori lebih suka memimilih restoran dan objek wisata dengan memiliki protocol kesehatan berkualitas tinggi. Hal ini menunjukkan bahwa wisatawan melenial sangat memperhatikan kualitas protocol kesehatan saat melakukan perjalanan wisata di era new normal. 
Tabel 1: Persepsi Wisatawan Milenial Terhadap Pariwisata di Era New Normal

\begin{tabular}{|c|c|c|c|c|c|c|c|c|}
\hline \multirow{2}{*}{ No } & \multirow{2}{*}{ Pernyataan } & \multicolumn{5}{|c|}{ Penilaian } & \multirow{2}{*}{ Jumlah } & \multirow{2}{*}{$\begin{array}{l}\text { Rata- } \\
\text { rata }\end{array}$} \\
\hline & & 1 & 2 & 3 & 4 & 5 & & \\
\hline 1 & Perjalanan wisata penuh resiko & 12 & 38 & 63 & 140 & 65 & 318 & 3,18 \\
\hline 2 & Covid 19 menciptakan kecemasan saat berwisata & 7 & 18 & 30 & 132 & 205 & 392 & 3,92 \\
\hline 3 & Perjalanan tidak aman karena Covid 19 & 9 & 26 & 54 & 136 & 130 & 355 & 3,55 \\
\hline 4 & $\begin{array}{l}\text { Covid } 19 \text { dapat mengurangi rencana perjalanan } \\
\text { wisata }\end{array}$ & 3 & 12 & 30 & 164 & 200 & 409 & 4,09 \\
\hline 5 & $\begin{array}{l}\text { Saat pariwisata dibuka saya akan mengurangi } \\
\text { melakukan perjalanan wisata ke pantai }\end{array}$ & 21 & 50 & 90 & 68 & 35 & 264 & 2,64 \\
\hline 6 & $\begin{array}{l}\text { Saat pariwisata dibuka saya akan mengurangi } \\
\text { melakukan perjalanan wisata ke pegunungan }\end{array}$ & 24 & 56 & 90 & 52 & 25 & 247 & 2,47 \\
\hline 7 & $\begin{array}{l}\text { Saat pariwisata dibuka saya akan mengurangi } \\
\text { melakukan perjalanan wisata ke kota besar }\end{array}$ & 11 & 42 & 69 & 112 & 85 & 319 & 3,19 \\
\hline 8 & $\begin{array}{l}\text { Covid } 19 \text { membuat perjalanan wisata lebih sering } \\
\text { bersama keluarga }\end{array}$ & 19 & 20 & $\begin{array}{c}10 \\
2\end{array}$ & 96 & 65 & 302 & 3,02 \\
\hline 9 & $\begin{array}{l}\text { Covid } 19 \text { membuat lebih suka tinggal di hotel saat } \\
\text { melakukan perjalanan wisata }\end{array}$ & 20 & 48 & 93 & 72 & 35 & 268 & 2,68 \\
\hline 10 & $\begin{array}{l}\text { Covid } 19 \text { membuat lebih suka memilih hotel } \\
\text { dengan memiliki protocol kesehatan berkualitas } \\
\text { tinggi }\end{array}$ & 8 & 6 & 24 & 88 & 295 & 421 & 4,21 \\
\hline 11 & $\begin{array}{l}\text { Covid } 19 \text { membuat lebih suka memilih restoran } \\
\text { dengan memiliki protocol kesehatan berkualitas } \\
\text { tinggi }\end{array}$ & 5 & 8 & 36 & 80 & 295 & 424 & 4,24 \\
\hline 12 & $\begin{array}{l}\text { Covid } 19 \text { membuat lebih suka memilih objek } \\
\text { wisata dengan memiliki protocol kesehatan } \\
\text { berkualitas tinggi }\end{array}$ & 4 & 10 & 30 & 100 & 280 & 424 & 4,24 \\
\hline
\end{tabular}

\subsection{Sikap wisatawan terhadap Pariwisata di Era New Normal}

Berdasarkan Tabel 2 menunjukkan bahwa penilaian sikap wisatawan milenial terhadap pariwisata di era new normal berada pada nilai 3.63 yang berarti dalam kategori setuju. Secara keseluruhan sikap wisatawan milenial terhadap pariwisata di era new normal lebih mengutamakan kebersihan dan keselamatan. Indikator sikap wisatawan milenial tertinggi adalah pada kategori lebih memperdulikan kebersihan. Hal ini menunjukkan bahwa wisatawan milenial sangat memperdulikan kebersihan saat melakukan perjalanan wisata di era new normal.

Tabel 2: Sikap Wisatawan terhadap Pariwisata di Era New Normal

\begin{tabular}{|c|c|c|c|c|c|c|c|c|}
\hline \multirow{2}{*}{ No } & \multirow{2}{*}{ Pernyataan } & \multicolumn{5}{|c|}{ Penilaian } & \multirow{2}{*}{ Jumlah } & \multirow{2}{*}{$\begin{array}{l}\text { Rata- } \\
\text { rata }\end{array}$} \\
\hline & & 1 & 2 & 3 & 4 & 5 & & \\
\hline 1 & $\begin{array}{l}\text { Covid } 19 \text { membuat saya lebih } \\
\text { peduli terhadap kebersihan }\end{array}$ & 0 & 2 & 6 & 68 & 400 & 476 & 4.76 \\
\hline 2 & $\begin{array}{l}\text { Covid } 19 \text { membuat saya lebih } \\
\text { memperhatikan kesalamatan } \\
\text { kesehatan }\end{array}$ & 0 & 2 & 6 & 84 & 380 & 472 & 4.72 \\
\hline 3 & $\begin{array}{l}\text { Covid } 19 \text { membuat saya lebih } \\
\text { peduli terhadap kebersihan } \\
\text { transportasi saat melakukan } \\
\text { perjalanan wisata }\end{array}$ & 1 & 4 & 12 & 120 & 315 & 452 & 4.52 \\
\hline 4 & Covid 19 membuat saya lebih & 1 & 4 & 6 & 108 & 335 & 454 & 4.54 \\
\hline
\end{tabular}




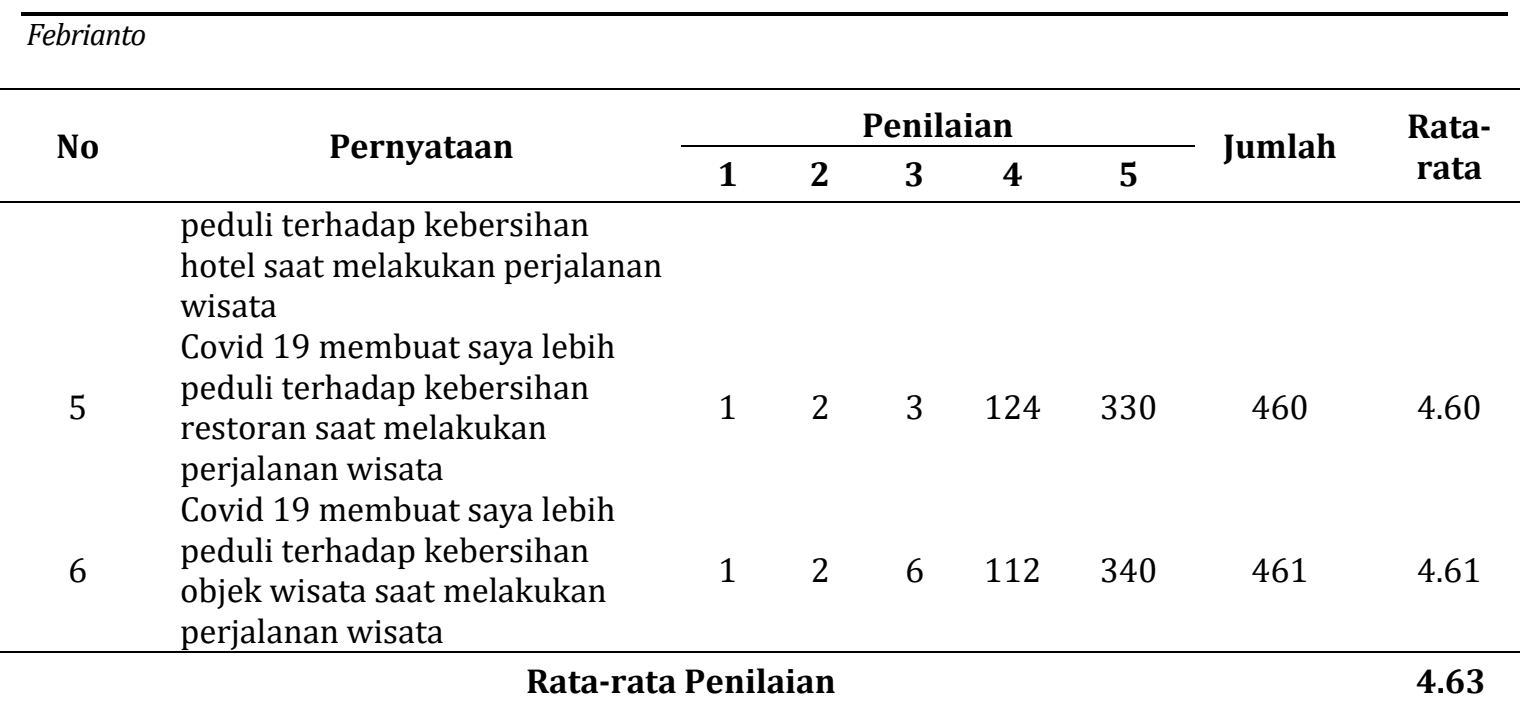

\section{KESIMPULAN}

Berdasarkan hasil pembahasan penelitian yang telah dilakukan, maka dapat disimpulkan bahwa persepsi wisatawan milenial terhadap Pariwisata di era new normal lebih mengutamakan kualitas protocol kesehatan baik di hotel, restaurant, transportasi, maupun di objek wisata. Begitu juga sikap wisatawan milenial terhadap Pariwisata di era new normal lebih memperdulikan tentang kesalamatan kesehatan dan kebersihan sata melakukan perjalananan wisata.

Berdasarkan simpulan pada penelitian ini maka saran peneliti adalah dalam upaya pengembangan Pariwisata di era new normal ini sebaiknya bagi penyedia layanan baik itu hotel, transportasi, restoran dan objek wisata agar mempersiapkan protocol kesehantan dengan kualitas terbaik dan tersertifikasi oleh pemerintah. Tidak hanya itu keselamatan kesehatan dan kebersihan adalah kunci dari pariwisata di era new normal ini.

\section{DAFTAR PUSTAKA}

Badan Pusat Statistik. (2018). Profil generasi milenial indonesia. Jakarta: Kementerian pemberdayaan perempuan dan perlindungan anak

Badan Pusat Statistik. (2020). Diakses dari www.bps.go.id

Garikapati, V. M, et al. (2016). Activity patterns, time use and travel of millennials: A generation in transition?. Journal Transport

Reviews, (5), 558-584

Hong, Y. et al. (2020). The impact of covid-19 on tourist satisfaction with $\mathrm{b} \& \mathrm{~b}$ in zhejiang, china: an importance-performance analysis. International Journal of Environmental Research and Public Health. Vol 17

Kodhyat, H. (1998). Sejarah pariwisata dan perkembangannya di indonesia. Jakarta: Grasindo

Kompas. (2020). Pariwisata bali akan dibuka untuk wisatawan nusantara pada $31 \quad$ Juli https://travel.kompas.com/read/20 20/07/02/114000627/pariwisatabali-akan-dibuka-untuk-wisatawannusantara-pada-31-juli-?page=all

Kotler, P. (1993). Manajemen pemasaran (analisis, perencanaan, implementasi dan pengendalian). Volume satu, Edisi ketujuh, Terj. Adi Zakaria Afiff, FE UI, Jakarta.

Liputan 6. (2020). Sektor pariwisata nyaris tumbang akibat corona covid 19, menparekraf masih siapkan solusi.

https://www.liputan6.com/lifestyle /read/4209455/sektor-pariwisatanyaris-tumbang-akibat-coronacovid-19-menparekraf-masihsiapkan-solusi

Murianto. (2014). Potensi dan persepsi masyarakat serta wisatawan terhadap pengembangan ekowisata di desa aik berik, lombok tengah. 
Febrianto

Jurnal Master Pariwisata, Vol. 1, No 1, pp. 43-64

Nazheen, S., Hong, X., \& Din, N. U. (2020). Covid 19 crises and tourist travel risk perception. SSRN:https://ssrn.com/abstract $=35$ 92321orhttp://dx.doi.org/10.2139/ ssrn.3592321

Okezone. (2020). New normal industri pariwisata siapkan protokol kesehatan. https://economy.okezone.com/read /2020/06/02/320/2223145/newnormal-industri-pariwisata-siapkanprotokol-kesehatan

Pendit, N. (2003). Ilmu pariwisata sebuah pengantar perdana. Jakarta : Pradnya Paramitha

Pitana, I. G. \& Gayatri, P. G. (2005). Sosiologi Pariwisata. Yogyakarta: Andi

Sedarmayanti \& Hidayat, S. (2002). Metodologi Penelitian. Bandung: Mandar Maju

Suranto, A. (2010). Komunikasi Sosial Budaya. Yogyakarta: Graha Ilmu

Slameto. (2010). Belajar dan faktor yang mempengaruhinya. Jakarta: Rineka

Sugiyono. (2002). Metode Penelitian Bisnis. Bandung: Alfabeta

Sumarwan, U. (2003). Perilaku konsumen teori \& penerapannya dalam pemasaran. Cetakan Pertama. Jakarta: Graha Ilmu

Sunaryo. (2004). Psikologi untuk pendidikan. Jakarta: EGC

Suprapti, W. (2010). Prilaku konsumen pemahaman dasar dan aplikasinya dalam strategi pemasaran. Bali: Udayana University Press

Suryani, T. (2008). Perilaku konsumen: Implikasi pada strategi pemasaran. Yogyakarta: Graha Ilmu

Thoha, M. (2003). Perilaku organisasi: konsep dasar dan aplikasinya. Jakarta: PT. Raya Grafindo Persada

Undang-Undang Republik Indonesia Nomor 10. (2009). Tentang kepariwisataan

Walgito, B. (2004). Pengantar psikologi Umum. Jakarta: Penerbit Andi 